\title{
Obesity, overweight and underweight among adults in an urban community in Yemen
}

\author{
A.A. Gunaid ${ }^{7}$
}

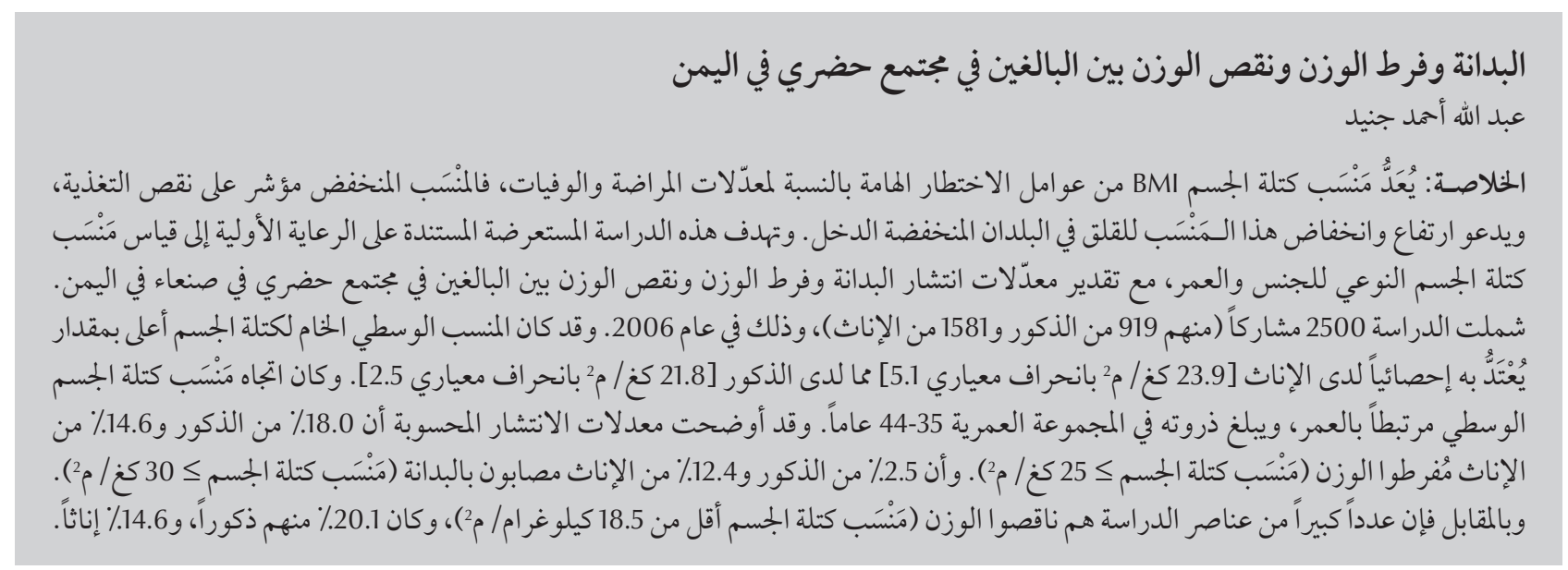

ABSTRACT High body mass index (BMI) is an important risk factor for morbidity and mortality, while low BMI is an indicator of undernutrition; both may be concerns in low-income countries. This cross-sectional, primarycare based study aimed to measure the sex and age-specific mean BMI and estimate the prevalence of obesity, overweight and underweight among adults in an urban community in Sana'a, Yemen. A total of 2500 subjects (919 males and 1581 females) were recruited in 2006. The crude mean BMI for all ages was significantly higher in females [23.9 (SD 5.1) kg/ $\mathrm{m}^{2}$ ] than males [21.8 (SD 8.9) kg/ $\left.\mathrm{m}^{2}\right]$. The mean BMI trend was associated with age, with a peak in the age group 35-44 years. Calculated prevalence showed $18.0 \%$ of males and $14.6 \%$ of females were overweight $\left(\mathrm{BMI} \geq 25 \mathrm{~kg} / \mathrm{m}^{2}\right)$ and $2.5 \%$ of males and $12.4 \%$ of females were obese $\left(\mathrm{BMI} \geq 30 \mathrm{~kg} / \mathrm{m}^{2}\right)$. In contrast a substantial number of subjects were underweight $\left(\mathrm{BMI}<18.5 \mathrm{~kg} / \mathrm{m}^{2}\right): 20.1 \%$ of males and $14.6 \%$ of females.

\section{Obésité, surpoids et insuffisance pondérale chez des adultes d'une communauté urbaine au Yémen}

RÉSUMÉ Un indice de masse corporelle élevé représente un facteur de risque important de morbidité et de mortalité, alors qu'il s'agit d'un indicateur de dénutrition lorsqu'il est faible; les deux cas sont des motifs de préoccupation dans les pays à faible revenu. La présente étude transversale sur les soins primaires visait à mesurer l'indice de masse corporelle moyen en fonction de l'âge et du sexe et à estimer la prévalence de l'obésité, du surpoids et de l'insuffisance pondérale chez des adultes dans une communauté urbaine à Sanaa (Yémen). Au total, 2500 sujets (919 hommes et 1581 femmes) ont été recrutés en 2006. La moyenne brute de I'indice de masse corporelle tous âges confondus était significativement plus élevée chez les femmes $\left(23,9 \mathrm{~kg} / \mathrm{m}^{2}\right.$ [ET 5,1]) que chez les hommes $\left(21,8 \mathrm{~kg} / \mathrm{m}^{2}\right.$ [ET 8,9]). La tendance moyenne de l'indice de masse corporelle a été associée à l'âge, avec un pic dans le groupe des patients âgés de 35 à 44 ans. Le calcul de la prévalence a révélé que $18,0 \%$ des hommes et 14,6\% des femmes étaient en surpoids (indice de masse corporelle $\geq 25 \mathrm{~kg} / \mathrm{m}^{2}$ ) et $2,5 \%$ des hommes et $12,4 \%$ des femmes étaient obèses (indice de masse corporelle $\geq 30 \mathrm{~kg} / \mathrm{m}^{2}$ ). En revanche, un nombre important de sujets souffrait d'insuffisance pondérale (indice de masse corporelle $<18,5 \mathrm{~kg} / \mathrm{m}^{2}$ ) : 20,1\% des hommes et $14,6 \%$ des femmes. 


\section{Introduction}

Overweight and obesity are defined by the World Health Organization (WHO) as abnormal or excessive fat accumulation that may impair health [1]. WHO projects that by 2015 , approximately 2.3 billion adults will be overweight and more than 700 million adults will be obese [1]. In low-income countries the problems of overweight and obesity have achieved global recognition only during the past decade, in contrast to underweight, malnutrition and infectious diseases which have always dominated as concerns [2] Excess body weight is the sixth most important risk factor contributing to the overall burden of disease worldwide [2]. There is an overall consensus that obesity poses a significant risk for the development of cardiovascular disease, alterations in glucose metabolism and certain cancers, and reduces life expectancy [3]. Body mass index (BMI) is a simple index of weight-for-height that correlates reasonably with body fat content. It is also a measure of underweight in adults, specifically in women, for whom a BMI $<18.5 \mathrm{~kg} / \mathrm{m}^{2}$ is an indicator of maternal undernutrition [4].

The objective of this study was to measure mean BMI and to estimate the prevalence of obesity, overweight and underweight by BMI categories. It was hoped that this work would highlight the burden of obesity and underweight as risk factors for ill-health in Yemen among adults in an urban community. To the best of our knowledge, this is the first published data on BMI trends in Yemen.

\section{Methods}

\section{Study setting and sample}

This survey was conducted during the first half of 2006. The study protocol was approved by the ethics committee at our university. The study sample was derived from an urban community population attending an outpatient general medical practice clinic in Sana'a city, Yemen. Subjects from this urban community included in the study were adult males and females aged 20 years or over, who were registered for primary care services. Individuals aged $<20$ years, and those with chronic debilitating diseases were excluded from the study.

A random sample was drawn from the general practitioners' list first by numbering all the individual members in the target population, and then computer-generating random numbers from that list. The sample size was calculated using the WHO Epi-Info software, version 6.02. Taking into consideration the following criteria: target population (males and females aged $\geq 20$ years) 10000 subjects; expected frequency of high BMI 3.5\% (as no previous data were available in Yemen); worse expected value $4.0 \%$; the sample size calculated at $90 \%$ confidence interval was 2677.

After obtaining written consent, each participant was invited to attend in the morning for clinical assessment using a standard protocol including history of a chronic disease, age and sex and height and weight measurements. BMI was calculated as recommended by WHO as: body weight $(\mathrm{kg})$ /square height $\left(\mathrm{m}^{2}\right)[4]$.

Mean BMI was estimated for each sex age groups for adults aged 20 years and older. BMI was also categorized according to the WHO criteria as: underweight $\left(\right.$ BMI $\left.<18.5 \mathrm{~kg} / \mathrm{m}^{2}\right)$, normal weight (BMI 18.5-24.9 kg/ $\mathrm{m}^{2}$ ), overweight (BMI $25-29.9 \mathrm{~kg} /$ $\left.\mathrm{m}^{2}\right)$ and obesity $\left(\mathrm{BMI} \geq 30 \mathrm{~kg} / \mathrm{m}^{2}\right)$ [4]. Age groups were categorized at 10year interval from $\leq 24$ to $\geq 65$ years. The underweight (thin) subjects were further subclassified as recommended by the WHO into 3 grades [4] as: grade 1 (mild thinness, BMI 17.0-18.49 kg/ $\mathrm{m}^{2}$ ), grade 2 (moderate thinness, BMI $16.0-16.99 \mathrm{~kg} / \mathrm{m}^{2}$ ) and grade 3 (severe thinness, BMI $\left.<16.0 \mathrm{~kg} / \mathrm{m}^{2}\right)$. Calculated prevalence rates of underweight, overweight and obesity by age and sex were based on the BMI categories mentioned above.

\section{Data analysis}

Data were entered into a personal computer and statistical analysis was conducted using 3 statistical packages: SPSS, version 9.0 for Windows, EpiInfo, version 6.02, and Confidence Interval Analysis, version 1.0. Continuous variables were expressed as mean and standard deviation (SD) and a 2-tailed t-test was used for calculating statistical significance. Confidence intervals (95\% CI) were calculated in order to indicate precision of sample estimate, variability of the characteristics being studied and the degree of confidence required. Data were also expressed as median and interquartile range (IQR) in order to show the central tendency and its upper and lower quartiles as a preferred measure of range to use with skewed distributions. Categorical variables were expressed as numbers and percentages and the difference was measured by the chi-squared test. Significance was considered at $P$-value $<0.05$.

\section{Results}

\section{Basic characteristics}

A total of 2677 subjects aged $\geq 20$ years were invited to participate in the study The number of people responding was 2500 [1581 females (63.2\%) and 919 males $(36.8 \%)]$, representing an overall participation rate of $93.4 \%$.

Data on the basic characteristics of study population showed that males and females were age matched. The median age of the study sample was 38 (IQR 20) years for males and 40 (IQR 20) years for females, and the mean age was 40.8 (SD 14.5) years for males and 41.2 (SD 14) years for females.

Males were significantly taller than females [mean height 163.4 $($ SD 6.7$) \mathrm{cm}$ versus $151.8(S D 6.1) \mathrm{cm}](P<0.001)$. Males also had a higher mean weight 
value than females $[58.4(S D$ 11.4 $) \mathrm{kg}$ versus $55.0(\mathrm{SD} 12.4) \mathrm{kg}](P<0.001)$.

\section{Prevalence of overweight, obesity and underweight}

A total of 808 out of 2500 adults (32.3\%) were overweight and a quarter of these $(n$ $=220$ ) were obese, an overall prevalence of obesity of $8.8 \%$. A higher proportion of females than males were overweight (26.8\% versus $18.0 \%$ respectively) and obese ( $12.5 \%$ versus $2.5 \%$ respectively) (Table 1). In contrast, more males than females were underweight (20.1\% versus $14.6 \%$ respectively).

\section{Mean BMI values by age and sex}

The mean BMI was significantly higher overall in females than in males BMI [23.9 (SD 5.1) $\mathrm{kg} / \mathrm{m}^{2}$ versus 21.8 (SD $\left.3.9) \mathrm{kg} / \mathrm{m}^{2}\right](P<0.001)$ (Table 2). Our estimates of mean BMI as a primary outcome show that the trend was associated with age, with the greatest association between 35-44 years of age, and the lower or flattened association in younger and older ages. Atage 35-44 years, mean BMI was significantly higher in females than in males $\left[25.3(\right.$ SD 5.2$) \mathrm{kg} / \mathrm{m}^{2}$ versus $\left.22.8(\mathrm{SD} 3.9) \mathrm{kg} / \mathrm{m}^{2}\right](t=6.47, \mathrm{df}$ $=646, P<0.001)$. For other age groups, the mean BMI was also significantly higher in females than in males, except for the age group 20-24 years.

\section{Prevalence of overweight, obesity and underweight by BMI categories}

Table 3 shows that $18.0 \%$ of males and $26.8 \%$ of females were overweight (Yates corrected $\chi^{2}=24.5, P<0.001$ ) and $2.5 \%$ of males and $12.4 \%$ of females were obese (Yates corrected $\chi^{2}=70.6, P$ $<0.001)$. The prevalence of underweight was $20.1 \%$ in males and $14.6 \%$ in females Yates corrected $\left(\chi^{2}=12.4, P<0.001\right)$. Calculating the mean BMI for each body weight category showed that the overweight subjects had mean BMI of $26.9($ SD 1.3$) \mathrm{kg} / \mathrm{m}^{2}$ in males and 27.2 (SD 1.4) $\mathrm{kg} / \mathrm{m}^{2}$ in females, and that the obese subjects had mean BMI 32.5 (SD 2.3) $\mathrm{kg} / \mathrm{m}^{2}$ in males and 33.1 (SD 3.0) $\mathrm{kg} / \mathrm{m}^{2}$ in females. The underweight males and females had the same mean BMI of $16.9($ SD 1.2$) \mathrm{kg} / \mathrm{m}^{2}$.

\section{Analysis of underweight}

Among the underweight subjects, mild thinness was noted among $60.5 \%$ and $51.9 \%$ of thin males and females respectively (Yates corrected $\chi^{2}=2.7, P=0.09$ ), moderate thinness among $20.5 \%$ and $29.9 \%$ of thin males and females respectively (Yates corrected $\chi^{2}=4.2, P=0.04$ ) and severe thinness among $19.0 \%$ and $18.2 \%$ of thin males and females respectively (Yates corrected $\chi^{2}=0.0, P=0.95$ ) (Table 4). A subgroup analysis of data of underweight women showed that out of the 231 adult females with BMI $<18.5$ $\mathrm{kg} / \mathrm{m}^{2}, 141(61.0 \%)$ were of reproductive age (20-40 years). The mean age of this subgroup was 28.8 (SD 6.2) years, their mean BMI was 17.0 (SD 1.1) kg/ $\mathrm{m}^{2}$ and their median BMI was 17.3 (IQR $1.5) \mathrm{kg} / \mathrm{m}^{2}$. Their mean height was 153.5 (SD 6.6) $\mathrm{cm}$, and median height was 153.0 (IQR 9.5 ) cm. It can be assumed that they had undernutrition by BMI criteria, yet only $7.0 \%$ of them had short stature (height $<145 \mathrm{~cm}$ ).

\section{Discussion}

In this study we used both mean values and categories of BMI to describe the spectrum of body weight status in an urban community in Yemen. Using mean BMI as a primary outcome, we found age-specific and sex-specific differences in the population distribution of mean BMI values across different age groups in both sexes. In addition, using BMI categories as a secondary outcome, we found that about half of the study population had normal BMI category, with both overweight and obesity almost 2-fold more frequent than underweight.

BMI is an anthropometric measure that provides the most useful, albeit crude, population-level measure of obesity and underweight [4]. WHO therefore proposed the use of BMI to monitor both undernutrition and overweight. Interpretation of BMI values are considered as essentially independent of height except for the very tall (height above $1.90 \mathrm{~m}$ ) and the very short (height below $1.50 \mathrm{~m}$ ), as the values would then be height-biased $[4,5]$. Analysis of data from 2 large clinical trials has shown that all measures of adiposity correlated with each other and with incident cardiovascular events $[6,7]$. In clinical practice, BMI should be considered as a tool for the initial clinical assessment of total body fatness, and waist circumference as a tool for assessing body fat distribution, especially in those with a $\mathrm{BMI}<30 \mathrm{~kg} / \mathrm{m}^{2}[8]$.

The global burden of disease attributable to high BMI include type 2 diabetes, hypertensive disease, ischaemic

\begin{tabular}{|c|c|c|c|c|c|c|c|c|c|}
\hline \multirow[t]{3}{*}{ Sex } & \multicolumn{9}{|c|}{ BMI category } \\
\hline & \multicolumn{3}{|c|}{$<18.5 \mathrm{~kg} / \mathrm{m}^{2}$} & \multicolumn{3}{|c|}{$25-29.9 \mathrm{~kg} / \mathrm{m}^{2}$} & \multicolumn{3}{|c|}{$\geq 30 \mathrm{~kg} / \mathrm{m}^{2}$} \\
\hline & No. & $\%$ & $95 \% \mathrm{Cl}$ & No. & $\%$ & $95 \% \mathrm{Cl}$ & No. & $\%$ & $95 \% \mathrm{Cl}$ \\
\hline Male & 185 & 20.1 & $17.5-22.7$ & 165 & 18.0 & $15.5-20.4$ & 23 & 2.5 & $1.6-3.7$ \\
\hline Female & 231 & 14.6 & $12.9-16.4$ & 423 & 26.8 & $24.6-28.9$ & 197 & 12.5 & $10.8-14.1$ \\
\hline Both sexes & 416 & 16.6 & 15.2-18.1 & 588 & 23.5 & $22.0-25.2$ & 220 & 8.8 & $7.7-10.0$ \\
\hline
\end{tabular}

$B M I=$ body mass index $; C l=$ confidence interval. 


\begin{tabular}{|c|c|c|c|c|c|c|}
\hline \multirow{2}{*}{ Age range (years) } & \multicolumn{3}{|c|}{ Males } & \multicolumn{3}{|c|}{ Females } \\
\hline & No. & $\begin{array}{l}\text { Mean (SD) BMI } \\
\quad\left(\mathrm{kg} / \mathrm{m}^{2}\right)\end{array}$ & $95 \% \mathrm{Cl}$ & No. & $\begin{array}{c}\text { Mean (SD) BMI } \\
\left(\mathrm{kg} / \mathrm{m}^{2}\right)\end{array}$ & $95 \% \mathrm{Cl}$ \\
\hline $20-24$ & 94 & $20.4(3.5)$ & 19.7-21.0 & 165 & $20.7(3.8)$ & $20.0-21.2$ \\
\hline $25-34$ & 262 & $21.4(3.5)$ & 21.0-21.9 & 390 & $23.2(4.6)$ & $22.7-23.7$ \\
\hline $35-44$ & 242 & $22.8(3.9)$ & $22.3-23.3$ & 406 & $25.3(5.2)$ & $24.8-25.8$ \\
\hline $45-54$ & 135 & $22.5(4.1)$ & $21.8-23.2$ & 293 & $25.1(5.4)$ & $24.4-25.7$ \\
\hline $55-64$ & 103 & $21.8(4.3)$ & $21.0-22.7$ & 205 & $23.9(5.2)$ & $23.0-24.6$ \\
\hline $65+$ & 83 & $20.8(3.6)$ & $20.0-21.6$ & 122 & $23.0(4.8)$ & $22.2-23.9$ \\
\hline Total & 919 & $21.8(3.9)$ & $21.6-22.0$ & 1581 & $23.9(5.1)$ & $23.6-24.0$ \\
\hline
\end{tabular}

$B M I=$ body mass index $; S=$ standard deviation $; C I=$ confidence interval .

heart disease, ischaemic stroke, colon cancer, postmenopausal breast cancer, endometrial cancer in women and osteoarthritis [9-11]. Data from the Prospective Studies Collaboration, which analysed 900000 adults, demonstrated a 30\% increase in all-cause mortality for every increase of 5 units in BMI above a BMI of $25 \mathrm{~kg} / \mathrm{m}^{2}$ [12]. Preliminary analysis of the global burden of disease associated with higher BMI, suggested that the population distribution of BMI values for men and women in each age group provided more valuable information than simply the proportions of the population who were classified as overweight and obese [9]. Also in the majority of the available data worldwide, the mean BMI increases with age and then starts to fall with rising age [9].
Our data provide the same information for Yemen. The highest mean BMI for both males and females in our study was in the age group 35-44 years, as compared with the age group 45-59 years in some other countries in the Eastern Mediterranean region such as Saudi Arabia [13], Jordan [14] and Islamic Republic of Iran [15].

WHO now accepts a BMI of 25.0 $\mathrm{kg} / \mathrm{m}^{2}$ or higher as abnormal; the overweight category is classified as obese when BMI is $30.0 \mathrm{~kg} / \mathrm{m}^{2}$ or more [9]. The International Obesity Task Force estimates that at present at least 1.1 billion adults are overweight, including 312 million who are obese [2]. In the past 20 years, the rates of obesity have tripled in developing countries, where the population has been adopting modern lifestyles involving decreased physical activity and overconsumption of cheap, energy-dense food [16]. In this study, out of 2500 adults screened in an urban community in Yemen, a total of 808 had were overweight and 220 of them were obese, with a female predominance in the prevalence of both overweight and obesity, i.e. more than one-third of our study population were either overweight or obese. In subjects aged $20-100$ years in our study, the calculated crude prevalence of overweight was $26.8 \%$ for females and $18.0 \%$ for males; and the prevalence of obesity was $12.5 \%$ for females and $2.5 \%$ for males. The WHO Global Infobase reported that in 2010 in Yemen, the prevalence of overweight for subjects aged 15-100 years was $32.2 \%$ for females and $24.6 \%$

\begin{tabular}{|c|c|c|c|c|c|}
\hline Sex/BMI category & No. & $\%$ & $95 \% \mathrm{Cl}$ & $\begin{array}{c}\text { Mean (SD) BMI } \\
\left(\mathrm{kg} / \mathrm{m}^{2}\right)\end{array}$ & $\begin{array}{c}\text { Median (IQR) BMI } \\
\left(\mathrm{kg} / \mathrm{m}^{2}\right)\end{array}$ \\
\hline \multicolumn{6}{|l|}{ Males $(n=919)$} \\
\hline$<18.5 \mathrm{~kg} / \mathrm{m}^{2}$ & 185 & 20.1 & $16.8-17.0$ & $16.9(1.2)$ & $17.3(1.5)$ \\
\hline $18.5-24.9 \mathrm{~kg} / \mathrm{m}^{2}$ & 546 & 59.4 & $21.4-21.7$ & $21.5(1.8)$ & $21.5(2.8)$ \\
\hline $25-25.9 \mathrm{~kg} / \mathrm{m}^{2}$ & 165 & 18.0 & 26.7-27.1 & $26.9(1.3)$ & $26.7(1.9)$ \\
\hline$\geq 30 \mathrm{~kg} / \mathrm{m}^{2}$ & 23 & 2.5 & $31.5-33.5$ & $32.5(2.3)$ & $31.6(3.5)$ \\
\hline \multicolumn{6}{|l|}{ Females $(n=1581)$} \\
\hline$<18.5 \mathrm{~kg} / \mathrm{m}^{2}$ & 231 & 14.6 & $16.7-17.0$ & $16.9(1.2)$ & $17.0(1.6)$ \\
\hline $18.5-24.9 \mathrm{~kg} / \mathrm{m}^{2}$ & 730 & 46.2 & $21.6-21.9$ & 21.7 (1.9) & $21.6(3.3)$ \\
\hline $25-25.9 \mathrm{~kg} / \mathrm{m}^{2}$ & 423 & 26.8 & $27.1-27.3$ & $27.2(1.4)$ & $27.1(2.3)$ \\
\hline$\geq 30 \mathrm{~kg} / \mathrm{m}^{2}$ & 197 & 12.4 & $32.6-33.5$ & $33.1(3.0)$ & $32.4(3.3)$ \\
\hline
\end{tabular}

$C I=$ confidence interval; $S D=$ standard deviation; $I Q R=$ interquartile range $(25 \%, 75 \%)$; 


\begin{tabular}{|c|c|c|c|c|c|c|c|c|c|}
\hline \multirow[t]{3}{*}{ Sex } & \multicolumn{9}{|c|}{ BMI category } \\
\hline & \multicolumn{3}{|c|}{$<16 \mathrm{~kg} / \mathrm{m}^{2}$} & \multicolumn{3}{|c|}{$16-16.9 \mathrm{~kg} / \mathrm{m}^{2}$} & \multicolumn{3}{|c|}{$17-18.5 \mathrm{~kg} / \mathrm{m}^{2}$} \\
\hline & No. & $\%$ & $95 \% \mathrm{Cl}$ & No. & $\%$ & $95 \% \mathrm{Cl}$ & No. & $\%$ & $95 \% \mathrm{CI}$ \\
\hline Male & 35 & 19.0 & $13.3-24.0$ & 38 & 20.5 & $14.7-26.4$ & 112 & 60.5 & $53.5-76.6$ \\
\hline Female & 42 & 18.2 & $13.2-23.2$ & 69 & 29.9 & $24.0-35.8$ & 120 & 51.9 & $45.5-58.4$ \\
\hline
\end{tabular}

$\mathrm{Cl}=$ confidence interval .

for males; and the prevalence of obesity was $6.2 \%$ for females and $2.0 \%$ for males [17]. Among a semirural population aged $\geq 35$ years in Yemen we have previously found that the age-standardized prevalence (for age range 35-64 years) of overweight was $35.4 \%$ for females and $26.8 \%$ for males [18]. As compared with other countries in the EMR, Table 5 shows that our prevalence rates for overweight and obesity among males and females were much lower than the corresponding rates for Saudi Arabia, Jordan, Egypt, Islamic Republic of Iran and Syrian Arab Republic; but comparable to the rates in Sudan [17]. This finding might be explained by the fact that Yemen is still a low-income country compared with other countries in the region, and adoption of a Western lifestyle has not yet been well established.

Analysis of the relationship between BMI and both morbidity and mortality has suggested that the association of BMI with most diseases is continuous. Therefore the use of mean BMI has replaced the usual categorical analysis based on rates of overweight and obesity $[9,10,12]$. At all ages and throughout the world, women generally have higher mean BMI and higher rates of obesity than men, for biological reasons [9]. The crude mean BMI of subjects aged 20-100 years in our study was significantly higher for females (23.9 $\left.\mathrm{kg} / \mathrm{m}^{2}\right)$ than for males $\left(21.8 \mathrm{~kg} / \mathrm{m}^{2}\right)$, with the age-dependent mean difference between females and males being maintained across all age groups. The WHO Global Infobase reported that in 2010 in Yemen, the mean BMI for subjects aged $15-100$ years was 23.1 $\mathrm{kg} / \mathrm{m}^{2}$ for females and $22.6 \mathrm{~kg} / \mathrm{m}^{2}$ for males [17]. Among a semi-rural population aged $\geq 35$ years in Yemen we have previously found that the mean BMI was $23.3 \mathrm{~kg} / \mathrm{m}^{2}$ for females and $23 \mathrm{~kg} / \mathrm{m}^{2}$ for males [18]. As compared with other countries in the EMR, Table 5 shows that in our study the crude mean BMI values for males and females were clearly lower than the crude mean BMI for males and females in Saudi

\begin{tabular}{|c|c|c|c|c|c|}
\hline Country & Year & Sex & $\begin{array}{c}\text { Mean BMI } \\
\left(\mathrm{kg} / \mathrm{m}^{2}\right)\end{array}$ & \% Overweight & $\%$ Obesity \\
\hline \multirow[t]{2}{*}{ SaudiArabia ${ }^{a}$} & 2005-2010 & Male & 26.6 & 63.1 & 23.0 \\
\hline & & Female & 27.6 & 63.8 & 36.4 \\
\hline \multirow[t]{2}{*}{ Jordan $^{\mathrm{a}}$} & 2005-2010 & Male & 26.1 & 57.5 & 19.6 \\
\hline & & Female & 27.9 & 63.4 & 37.9 \\
\hline \multirow[t]{2}{*}{ Egypt $^{a}$} & 2005-2010 & Male & 26.7 & 64.5 & 22.0 \\
\hline & & Female & 29.6 & 74.2 & 48.0 \\
\hline \multirow[t]{2}{*}{ Islamic Republic of Iran ${ }^{a}$} & 2005-2010 & Male & 24.9 & 48.5 & 10.0 \\
\hline & & Female & 26.5 & 57.8 & 29.5 \\
\hline \multirow[t]{2}{*}{ Syrian Arab Republic ${ }^{a}$} & 2005-2010 & Male & 24.9 & 48.4 & 12.4 \\
\hline & & Female & 26.1 & 57.2 & 24.6 \\
\hline \multirow[t]{2}{*}{ Sudan ${ }^{\mathrm{a}}$} & 2005-2010 & Male & 21.6 & 17.2 & 1.5 \\
\hline & & Female & 22.7 & 29.1 & 6.5 \\
\hline \multirow[t]{2}{*}{ Yemen $^{\mathrm{a}}$} & 2005-2010 & Male & 22.6 & 24.6 & 2.0 \\
\hline & & Female & 23.1 & 32.2 & 6.2 \\
\hline \multirow[t]{2}{*}{ Yemen $^{\mathrm{b}}$} & 2006 & Male & 21.8 & 18.0 & 2.5 \\
\hline & & Female & 23.9 & 26.8 & 12.4 \\
\hline
\end{tabular}

${ }^{a}$ Global Infobase. World Health Organization [17].

${ }^{b}$ Current study; males and females aged $20-100$ years. 
Arabia, Jordan, Egypt, Islamic Republic of Iran and Syrian Arab Republic; but comparable to those in Sudan [17]. This relatively lower mean BMI in our study might be attributed to a large number of individuals who belong to the normal and low BMI values.

Low BMI (underweight, BMI $<18.5$ $\mathrm{kg} / \mathrm{m}^{2}$ ), on the other hand, has recently been defined as chronic energy deficiency in adults who are underweight for their height due to inadequate food intake $[4,10]$. Low maternal BMI in particular is an indicator of maternal undernutrition and is a recognized risk factor for neonatal mortality [19]. Estimates of underweight prevalence among women of reproductive age (15-44 years) remain high in low- and middle-income countries, and have been used to calculate the global burden of disease attributable to undernutrition $[11,19,20]$. Maternal undernutrition ranges from $10 \%$ to $19 \%$ in most lowincome countries including Yemen, where more than $20 \%$ of women have a BMI less $18.5 \mathrm{~kg} / \mathrm{m}^{2}$ [19]. In this study, although the prevalence of underweight was significantly higher in males than in females, the severity of underweight was greater in females. In addition, many of our underweight females were at reproductive age, with some of them having short stature. In view of their low maternal BMI, these females are at increased risk of intrauterine growth restriction [20] leading to worse neonatal outcome; and those with maternal short stature are at an additional increased risk of worse pregnancy outcomes leading to increased frequency of caesarean delivery [21].

The limitation of this study was that it was a community study and not a subnational or national one. Although it presents the first data from Yemen on age-specific and sex-specific mean BMI values, and on the prevalence rates of both excess weight and underweight, further study on mean BMI trends in recent years in the country should be considered. In view of the epidemiological nature of the study, waist circumference measurement was not considered.
In conclusion, our findings confirm that in this community-based study in Yemen the spectrum of BMI values vary from high (excess body weight) to low (underweight). The crude mean BMI for all ages was significantly higher in females than in males. Mean BMI increased with age and then started falling with rising age. The prevalence rates of obesity and overweight had a female predominance and appeared to be relatively lower than in other countries in the region. A substantial number of subjects had low BMI with mild thinness being more common among males and moderate thinness more frequent among females.

\section{Acknowledgements}

The author wishes to thank the medical and nursing staff working in the general practice clinic for their kind cooperation. The author also is grateful to Dr Mohamed Al-Kobati for his statistical advice.

\section{References}

1. Health topics. Obesity. World Health Organization [online] (http://www.emro.who.int/health-topics/obesity/, accessed 6 October 2012)

2. Haslam DW, James WP. Obesity. Lancet, 2005, 366:1197-1209.

3. Eyre H, Kahn R, Robertson RM. Preventing cancer, cardiovascuP lar disease, and diabetes: a common agenda for the American Cancer Society, the American Diabetes Association, and the American Heart Association. Diabetes Care, 2004, 27:1812-1824.

4. Physical status: the use and interpretation of anthropometry. Report of a WHO Expert Committee. Geneva, World Health Organization, 1995 (Technical Report Series No. 854).

5. Obesity: preventing and managing the global epidemic. Geneva, World Health Organization, 2000 (WHO Technical Report Series No. 894).

6. Litwin SE. Which measures of obesity best predict cardiovascular risk? Journal of the American College of Cardiology, 2008, 52:616-619.

7. Gelber RP et al. Measures of obesity and cardiovascular risk among men and women. Journal of the American College of Cardiology, 2008, 52:605-615.

8. Cornier MA et al. Assessing adiposity: a scientific statement from the american heart association. Circulation, 2011, 124:1996-2019.

9. James WPT et al. Overweight and obesity (high body mass index). In: Ezzati $\mathrm{M}$ et al., eds. Comparative quantification of health risks: global and regional burden of disease attributable to selected major risk factors. Volume 1. Geneva, World Health Organization, 2004:497-596.

10. Finucane MM et al. Global Burden of Metabolic Risk Factors of Chronic Diseases Collaborating Group (Body Mass Index). National, regional, and global trends in body-mass index since 1980: systematic analysis of health examination surveys and epidemiological studies with 960 country-years and 9.1 million participants. Lancet, 2011, 377:557-567.

11. Ezzati $M$ et al. Comparative Risk Assessment Collaborating Group. Selected major risk factors and global and regional burden of disease. Lancet, 2002, 360:1347-1360.

12. Whitlock G et al. Prospective Studies Collaboration. Bodymass index and cause-specific mortality in 900000 adults: collaborative analyses of 57 prospective studies. Lancet, 2009, 373:1083-1096.

13. Al-Nuaim AR et al. High prevalence of overweight and obesity in Saudi Arabia. International Journal of Obesity and Related Metabolic Disorders, 1996, 20:547-552.

14. Ajlouni K, Jaddou H, Batieha A. Obesity in Jordan. International Journal of Obesity and Related Metabolic Disorders, 1998, 22:624-628.

15. Pishdad GR. Overweight and obesity in adults aged 20-74 in southern Iran. International Journal of Obesity and Related Metabolic Disorders, 1996, 20:963-965.

16. Hossain P, Kawar B, El Nahas M. Obesity and diabetes in the developing world-a growing challenge. New England Journal of Medicine, 2007, 356:213-215. 
17. WHO Global Infobase [online database] (https://apps.who. int/infobase/, accessed 6 October 2012).

18. Gunaid AA, Assabri AM. Prevalence of type 2 diabetes and other cardiovascular risk factors in a semirural area in Yemen. Eastern Mediterranean Health Journal, 2008, 14:42-56.

19. Black RE et al. Maternal and Child Undernutrition Study Group. Maternal and child undernutrition: global and regional exposures and health consequences. Lancet, 2008, 371:243-260.
20. Fishman SM et al. Childhood and maternal underweight. In: Ezzati $\mathrm{M}$ et al., eds. Comparative quantification of health risks: global and regional burden of disease attributable to selected major risk factors. Volume 1. Geneva, World Health Organization, 2004:39-161.

21. Ronsmans C, Holtz S, Stanton C. Socioeconomic differentials in caesarean rates in developing countries: a retrospective analysis. Lancet, 2006, 368:1516-1523.

\section{WHO handbook for guideline development}

Guidelines are recommendations intended to assist providers and recipients of health care and other stakeholders to make informed decisions. WHO has adopted internationally-recognized standards and methods for guideline development to ensure that guidelines are free from bias, meet a public health need and are consistent.

The handbook WHO handbook for guideline development provides stepwise advice on the technical aspects of developing a WHO guideline and the methods used. It aims to provide a clear path through the process and seeks to ensure that the resulting guidelines have credibility and meet WHO's criteria for content, methods and presentation, while remaining accessible and useful.

Further information about this and other WHO publications is available at: http://www.who.int/publications/en/ 